\title{
Socialization among peers: a study on racial relations among Brazilian children
}

Rita de Cássia Fazzi

Pontifical Catholic University of Minas Gerais

\begin{abstract}
The theme of racial relations presented in this article is based on the results of a sociological observation which occurred in two groups of children, from distinct socioeconomic backgrounds, studying at two public schools in the city of Belo Horizonte, Brazil. This study adopts the methodological perspective of the discovery of grounded theory formulated by Glaser \& Strauss (1970). The analysis of the empirical data intended to sociologically reconstruct the constitution of a prejudiced reality that emerges from the inter-subjective relationships established by children. While experimenting with a set of values, attitudes, behavior, beliefs and racial notions learned in other settings in their relationships, children learn what it means to be of one racial category or another, creating and re-creating the meaning of race and of prejudice. This article makes some concluding remarks highlighting the implications of the findings for an anti-racist policy in Brazil.
\end{abstract}

Keywords: racial prejudice in childhood; racial classification; racial discourse; anti-racist policy.

\section{Resumo}

O tema das relações raciais apresentado nesse artigo baseia-se nos resultados de uma observação sociológica realizada em dois grupos socioeconômicos diferentes de crianças inseridas em duas escolas públicas de Belo Horizonte, Brasil. O estudo adota a perspectiva metodológica da descoberta da teoria fundamentada nos dados formulada por Glaser \& Strauss (1970). A análise 
dos dados empíricos pretendeu reconstruir sociologicamente a constituição de uma realidade preconceituosa que emerge das relações intersubjetivas estabelecidas pelas crianças. Enquanto experimentando um conjunto de valores, atitudes, comportamentos, crenças e noções raciais aprendidos em outros ambientes em seus relacionamentos entre si, crianças aprendem o que significa ser de uma categoria racial ou de outra, criando e recriando o significado de raça e do preconceito. Esse artigo conclui com algumas observações sobre as implicações dos achados para uma política anti-racista no Brasil.

Palavras-chave: preconceito racial na infância; classificação racial; discurso racial; política anti-racista. 


\section{Socialization among peers: a study on racial relations among Brazilian children}

Rita de Cássia Fazzi

\section{1 - Introduction}

This article is a version of my doctoral thesis defended at the University Research Institute of Rio de Janeiro (IUPERJ), Brazil, in 2000. The central theme is racial prejudice in childhood predominantly among 8-9 year old Brazilian children. The article is divided into three parts: a discussion of the theoretical and methodological aspects that have grounded the collection and analysis of the data; the results of the research; and, finally, some concluding remarks highlighting the implications of the findings for anti-racist policies in Brazil.

\section{2 - Theoretical and methodological aspects}

The discussion on racial relations presented in this article is based on the results of a sociological observation of two groups of children, from distinct socioeconomic backgrounds, studying at two public schools in the city of Belo Horizonte, Minas Gerais, Brazil, in 1997 and 1998. The focus of the observations was the socialization among peers. This dimension presupposes that children should be regarded as active social actors who are competent in their diverse relationships and carry out an active role in their very own socialization process. While reflecting on the relationship between children and contexts, Lerner \& Lerner (1986: 91-92) affirm that children are processors and producers of their own development. What this establishes, therefore, is a circular function between the child and his/her context. The socialization process, according to these authors, involves the acquisition of behavioral and cognitive competence on the part of the child, who then responds to the demands put forth by a 
given environment. Hence, the child elaborates his/her own socialization experience, being that racial socialization is a part of this experience. As Cicourel (1974) points out, the child simultaneously develops a concept of social structure.

The social interactions that children establish among themselves are as important for their socialization as is their relationship with other socializing agents. This is also Thorne's (1995) stance in his study of children in two elementary schools in the United States. Thorne sought to show how children construct and experiment with gender identities in their relationships at school. Thorne's daily observations were concerned with "the workings of gender categories in social life" (Thorne 1995: 8) and with supporting "the view that gender is socially constructed" (Thorne 1995: 3). Thorne questions the concept of socialization used in great part of the literature regarding the social construction of gender in childhood due to the fact that these studies emphasize the passivity of those being socialized. According to Thorne it is important to take into consideration that children "act, resist, re-work and create; they influence adults as well as influenced by them." (Thorne 1995: 3).

This paper also argues that racial prejudice is a reality socially constructed by children and adults. The analysis of the empirical data intends to sociologically reconstruct the constitution of a prejudiced reality that emerges from the inter-subjective relationships established by children. The school environment is the privileged locus of children. In this social environment of relationships, children test a set of values, attitudes, behavior, beliefs and racial notions learned in other settings. While experimenting with these very notions in their relationships, children learn what it means to be of one racial category or another, and thus, create and recreate the meaning of race and of prejudice ${ }^{1}$.

Researching children's points of view regarding their own racial relationships required a methodology that permitted direct observation of the children. In this case, the main concern was not to interpret the actions and speech of the children from an adult's mind frame, which would include the own researcher's thoughts. Mehan \& Wood (1975), for

1 In this study, race should not be considered as a given concept due to the fact that races are not genuinely natural categories. Race is created and discovered by individuals and are artifacts of human culture. For a discussion on the concept of race in this sense see Hirschfeld (1996). 
example, showed that educational tests used to make critical judgments about children in American schools distorted the complexity of the reality by imposing an adult's point of view. This imposition, based on an adult's perspective, can result in dangerous decisions regarding the progress of these children in school, once the responses are analyzed according to the criteria of those who elaborated the tests. It is necessary for children to have the opportunity to explain their responses, because this process can reveal the reasoning involved in their decision-making.

This study adopts the methodological perspective of the discovery of grounded theory, as formulated by Glaser \& Straus (1970)2 ${ }^{2}$, based on systematic data that has been obtained and analyzed. In this sense, the observations focused on the manner in which the children elaborated their own racial experiences through their language and behavior.

The first phase of field work was conducted in a school located in a favela. From March through to June 1997, I carried out non-structured interviews with the children from this school. A total of 80 children were interviewed, in addition to others who participated in the taped conversations but who I was unable to identify by their names. In the second half of 1998, I began the observation of children in a school located in a middle class neighborhood. After one month of contact and based on the experience with the children living in the favela, I felt the need to elaborate a type of interview which would provide me with greater control of the situation. This is mainly due to the fact that during recess or even during Physical Education classes it was difficult to sustain a deeper conversation with the children, which could be attributed to the children's lack of time or to dispersed interaction occurring during these social situations. From November through to December 1997, I interviewed 27 children from the school in the favela and 22 children from the school in the middle class neighborhood. All of these children were 8 or 9 years old and in the third grade. The interviews were all recorded. The comparison of these two groups of children had the intention of grasping whether or not there were differences in the children's elaboration of racial categories and the meanings attached to them.

2 Glaser \& Strauss (1970: 3) affirm that: "By 'fit' we mean that the categories must be readily (not forcibly) applicable to and indicated by the data under study; by 'work' we mean that they must be meaningfully relevant to and be able to explain the behavior under study." 
Before reconstituting the social process involved in the construction of a racially prejudiced reality in the two "multiracial" groups of children being analyzed, it is worth briefly presenting the procedures adopted regarding racial classification. This problem has been the object of controversial debate particularly in the Brazilian Social Sciences.

This study starts from the premise that systems of racial thought vary among cultures. As Hirschfeld (1996) has argued, for example, the question of racial hybridity (the result of miscegenation) is treated differently by various systems of racial thought: "any system of racial thinking must provide some strategy for resolving ambiguity" (Hirschfeld 1996: 56). The strategy used to eliminate the intermediate racial categories in the United States was the "one drop rule," according to which children of a mixed racial background were treated as black within a bipolar system of classification. Nonetheless, many systems of classification do not utilize this rule, recognizing the existence of racial hybridity. In this case, the system of classification is multiple. It should also be noted that the author himself cites Brazil as an example.

Despite the recognition of the multiplicity of racial terms and the existence of a complex "calculation of racial identity", according to the expression utilized by Valle Silva (1994: 71), many researchers in Brazil have opted to use the bipolar system, differentiating between two categories: "black" and "white" or "white" and "non-white". The studies on racial inequality in Brazil conducted primarily from statistical analysis of data produced by the National Census and by National Household Sample Surveys (PNADS - Pesquisa Nacional por Amostra de Domicilios) aggregated the two census categories, black and pardo (brown), ${ }^{4}$ into the category black. Valle Silva (1985) justifies the adoption of a binary system of classification, having observed $t$ the lack of significant socio-economic and educational differences between "mulattoes" and "blacks". Both, he argued, suffer similar discrimination.

Qualitative research, which seeks to understand the racial dynamics in childhood, could not follow such a course, given that a significant number

3 The racial categories used throughout this text are the racial self classification chosen by the children and the racial categories used by cited researchers. In the last case the categories will appear in quotes. The racial self classification chosen by the children will appear after the child's name and age.

4 In Brazil, the Brazilian Institute of Geography and Statistics has been using this category in its census since 1950. Pardo refers to an intermediate racial category. The word in Portuguese is close to the meaning of the word "brown." Taken from: http://en.wikipedia.org/wiki/Pardo on 14/04/2008. 
of racial terms are employed in everyday circumstances in a highly complex manner. In a way, this may be considered a game, albeit a very serious one. This game of the classification self and others, is one of the social processes that are representative of the daily reality of children. This study, then, makes no attempt to aggregate terms into possible analytical concepts. Rather, it aims to understand the meaning of the racial categories adopted by the children themselves. In this manner, through the game of classification and of self-classification, in which the researcher asked the children to classify themselves and their classmates, it was possible to see that a certain consensus is socially constructed regarding racial identification.

The wide variety of terms used by the students to classify themselves and their peers creates a serious problem of translation, since the meanings involved do not always have correspondent terms in English. For that reason, I have opted to retain the terms in the original Portuguese and in italics. For example, the Brazilian term negro that is used by many people and activists to refer to any one with visible African descent can successfully be translated as "black" in English. However, the term preto also means "black" but without the identity connotations of the word negro. The term pardo utilized by the Brazilian census to refer to people of mixed descent may conveniently be translated as "brown." The most difficult of all to translate is moreno for its meaning is almost entirely contextdependent. It can be used to refer to women who used to be called brunettes in English, but it may also be used to refer to a very dark skinned person. Terms of racial abuse are even more difficult to translates.

How, then, do children construct and experience racial prejudice in their relationships at school? The answer to this question will consider prejudice in its attitudinal (stereotypes, sentiments and preferences) and behavioral (verbal aggression, rejection, the barrier to participating in a certain activity, etc.) manifestations. According to Hirschfeld (1996: 53), racial prejudice comprises "the notion that corporal differences in appearance signal differences in potential and value, that, in turn, legitimize invidious distinctions between races". Thus, expressions of racial prejudice would then include either attributing negative characteristics to a certain

5 The terms of racial abuse are produced by augmentative, diminutive or altered forms of the Brazilian words negro and preto. Some examples: negão, nego preto, pretão. 
racial category or acting, even if not consciously, in a manner that makes a specific group seem inferior.

In the next section, I present and discuss not only the categories of racial realities that emerged in the inter-subjective relations observed, but also the discourses elaborated by the children from the two groups involved in this social process.

\section{Results}

\subsection{Racial Classification and Racial Stereotypes}

The main characteristics of the system of classification used by the children in the two groups throughout this study include: (1) the multiplicity of categories and the gradation of colors existing among them; (2) the possibility of manipulation and of exchange among the categories, creating a contextual and circumstantial classification; (3) the identification of the Brazilian categories negro and preto that are interchangeable e not clearly distinct from one other by children; and (4) the hierarchy that locates the category negro/preto in an inferior position through the social process of stigmatization and the formation of stereotypes. In a child's world, being considered moreno or negro/preto is significantly important and can represent differentiated social treatment. A child classified as preto/negro has difficulty escaping the negative evaluations and depreciative commentaries associated with this category, potentially influencing one's self esteem much more so than those who consider the child as such or even those who are considered to be moreno. One of the problems with the type of classification based on appearance is the greater degree of uncertainty with regard to the moreno racial identity and the guarantee of non-discriminatory treatment in other social contexts, in other groups or in the individual's other life stages. The non depreciation of the moreno category makes the racial identification process during childhood more competitive and complex and therefore, more dynamic.

The children's speech that was observed in the two groups revealed the existence of negative attitudes in relation to the category preto/negro through three stereotypes: "pretos are ugly,"'pretos look like the devil" and "pretos are thieves.” 
The accounts below are from the group of lower class children:

Rute $^{6}$, 9 years old, defined as clara that means literally fair, said that being branca (white) is better than being preto/negro, justifying herself in this away: "Well, pretos, I don't like pretos. Pretos are ugly, I don't like the color...the color is ugly" and "I don't even like black (preto) for coloring".

Aloísio, 10 years old, who described himself as branco (white) in one situation and Moreno in other, stated that he would not like to be preto "because I don't like pretos...because their skin is different".

Geraldo, 10 years old, who described himself as moreno, does not think a classmate is pretty "because she is too preta." In addition, he said that all pretos are ugly.

In the group of the lower class children, when answering the following question - "would you like (or would you choose) to be preta?"- 26 of the 40 children directly responded with these affirmations: "I would not want to be preto because pretos are ugly" and "because it is an ugly color."

In light of such affirmations, what is truly considered ugly by these lower class children? Two answers were given by the children and referred to skin color and hair type. With respect to skin color, they emphasized "the entire face is preto," claiming for example that "there are some pretos that are preto, really preto, the only thing you can see is the white of their eyes. That's too ugly...". When this child was asked when she learned that being preto is ugly, as she had affirmed, she responded that she learned it by herself. When asked how she learned it, she said "When we see them, we stare at them and see they are pretos," revealing that the association between preto and ugliness is for this child self-evident, without the need for any explanation or consideration.

The children's emphasis on the aesthetic aspect, distinguishing between what is ugly and what is beautiful, suggests the development of visual racial prejudice, probably through verbal cues based on stereotypical patterns of beauty. From an early age, children learn, for example, that straight hair is what is considered beautiful hair. This pattern is reinforced given that compliments regarding frizzy hair are rare and even non-existent during childhood. Fernanda, 9 years old, morena, answered the question

6 The names used throughout this text are fictitious. The text will also use the racial self classification chosen by the children and will appear in italics. 
"Has anybody told you that your hair is pretty?" in the following manner: "No, nobody says that. Nenem [a classmate from another class who has straight hair]says our hair is hard (duro)." When I commented that I liked her hair she said: "I don't believe you." The intention of straightening hair is still very strong among the children who were observed. Even those that said that they liked their color affirmed that they did not like their hair. The expression "negra with hard hair" ("nega do cabelo duro") is still used by many as a form of abuse, as revealed by Sofia, morena, who was interviewed with Fernanda:"the boys from the street, when they see Fernanda, they always say something about her hair and when they see me they say the same thing. Like one day a boy said her hair was hard."

In the group of children from the school in the middle-class neighborhood, of the 35 children directly questioned, 19 said that pretos are ugly. A girl admitted that she did not think pretos were ugly, but if she were to choose, she would prefer being branca (white) "because people make fun of pretos, they keep saying that pretos are ugly." It should be noted that she excluded herself from the type of person who makes these negative evaluations.

The association of the category preto with the devil appeared primarily among the lower class children. For example, one of the children explained the fact that she did not want to be preto by affirming the following: "then we would look like the devil because we would be so preto." Or in other words, being preto is not good because the devil is preto. Afterwards, this same child explained that the devil "must be preto" because "he's ugly, right?" Another girl affirmed that "he's [the devil] too preto" and that "everything that is preto belongs to the devil," generalizing the representation that the devil is preto and expressing the stereotype that pretos are the devil. The symbolic representation of the devil as being preto/negro which emerged primarily among the lower class children, constitutes yet another foundation for the development of prejudice even if it is not considered a direct expression of racial prejudice. This is due to the fact that it is another negative cultural association, especially given the opposite representation of God being branco. Carolina, who described herself as morena escura (dark morena), had to create an explanation for the fact that angels are brancos during an Evangelical service, by saying that the souls of pretos "become 
white" when they die. Sara, who described herself as morena clara (lightskinned morena), affirmed that "pretos angels are bad."

The study of the representation that thieves are pretos began with a drawing made by Lúcia, 9 years old, branca, from the group of lower class children. The teacher asked for a drawing about a real city and an ideal city. In the drawing of the real city there was a thief colored in black, who was mugging another person colored in yellow (the child wrote the word "mugging" on the drawing and drew an arrow indicating this action). In the drawing of the ideal city, despite the fact that the child wrote that in this place "there were no thieves," there was also a thief colored in black. During the interview with this girl, I took the drawing and she explained it to me in the following manner: "This drawing is of the city. Here is a man mugging an old man. Here there is another man begging for money. Here is the place to throw away garbage. Here is a house with a family." I asked why she colored the man all in black. She replied: "Because...I colored him all in black because this is a mask, so you can only see his eyes, not his mouth, only his eyes. He is dressed in black so you can't see the clothes that he is wearing." Although the girl did not explicitly say that she colored the thief in black because thieves are pretos, she revealed the association between thief and being preto in her drawing.

Based on this conversation, I decided to include an experiment in the interviews, which I called the "mugging game." In this game, there were two dolls, a "white doll" and a "non-white doll", one of which would be mugged while going home. I would show the two dolls, the white doll and the nonwhite doll both of the same size, with the same clothes, shoes, and hat. I would then ask the child to choose which one would represent the thief in the game.

In the group of the lower class children, 20 out of the 24 children chose the non-white doll to be the thief. The experiment was done after a dialogue about the colors of the classmates, of the dolls, of their favorite activities and games, etc. This was done to ensure that the children recognized the different colors of the dolls. I also asked for explanations regarding their choice. Rosa, 9 years old, morena escura, justified her choice of the marron (brown) doll as the thief saying that it was "because the doll was just like... the shoes...the cap." Inês, 10 years old, loira (blond), chose the brown doll as 
the thief saying that "the face and clothes were strange." Geraldo, 10 years old, moreno, justified his choice by saying: "Because that one has lighter clothes and this one here has darker clothes, so this one looks like the thief and that one looks like the police officer." Eduardo, 9 years old, branco, chose the non-white doll as the thief and explained: "This one here has a mugger's hat." When asked if the hat of the other doll was not the same as the one he chose, he replied: "Yeah, but that one looks like it was trained to take money."

All of these justifications called attention to aspects that were not consistent with the reality, such as the cap, shoes and clothes. This can be interpreted in two ways. On the one hand, it could mean the child did not want to explicitly say that the thief was preto, which in this case would illustrate a self imposed censorship regarding one's racial considerations. On the other, it could mean the association thief-preto, occurring at a nondiscursive level, was projected in this game and, thus created a certain difficulty for the child to explain his/her choice. The second and last accounts given above were made in reference to the face of the doll. Since the dolls were the same, the accounts may have wanted to refer to the color of the face. A 9 year old girl, morena, justified her choice of which doll would be the thief by saying: "No, not this one. This other is preto."

In the group of the middle class children, the association thief-preto was also studied by using the "mugging game" with the dolls. The children were asked to choose which would be the mugger in an enactment of this crime. Of the 22 children that participated in the game, 14 chose the non-white doll as the thief. The answers to justify the choice include: "The neguim (little black guy)` because he's cooler", "this one, he's showing off more... and because his cap and clothes are really cool", "I think it is this one, not because of the color but because of the clothes, the way he is dressed, his style, his face, because of the way he is." None of these answers explains the reason for choosing the clothes, given that the two dolls had the same style of clothes, with only a variation in the color of the outfits. The last child stated "it is not because of the color" attempting to show that she was not prejudiced, but the reasons given for the justification of the choice of

7 "Little black guy" ("neguim") is the diminutive of the Brazilian category "negro" but without the last letters of that word. 
the doll - "the darker one"-, according to this same child did not seem to even convince him/her. This child repeated this justification three times: "it's just the doll's style." Two other children stated: “Yeah, I don't know, he has the face of a thief" and "because he's wearing a thief's hat. He's negro (black)." This directly expresses the social perception that a thief is preto. In the interview carried out with both Juarez, branco (white), and Tadeu, moreno, there was a dispute over which doll would be the thief. Tadeu chose the white doll and Juarez chose the non-white doll. When I informed both that there would also be a police officer, Tadeu agreed to represent the police officer. After playing, I asked Juarez about the color of the thief and he answered: "He was preto." Juarez justified his choice by saying: "Well, because this one here has more of a face of a thief!"

\subsection{Daily prejudiced behavior}

Prejudiced behavior manifests itself through daily practices of making fun of and swearing at others. In an interview conducted with Lúcia, 9 years old, branca, from the group of the lower class children, I asked if she would like to be preta and she answered "No." I asked her what was the reason for her answer and she said: "I would like to, but being preto does not match being branco (white). Because it would be like this. The branca (white) person always does this: You monkey, hey monkey, monkey, little monkey!" In another interview, Fernanda, 8 years old, morena, answered the same question in the following manner: "Oh God no! Not me!" emphatically denying this possibility. When I asked why Fernanda said that, she replied: "It's annoying because when we walk down the street ... when we walk down the street other people shout: hey monkey! hey monkey!". Two weeks after this conversation, Fernanda asked me to play dolls with her and we went to the art room. During the activity, Fernanda said she would like to be of the raça branca (white race) and said that "being of the raça preta (black race) is really bad." I asked her: "Bad in what sense?" And she answered: "People yell rude words at us." I then asked if she had already been sworn at. Fernanda said yes but would not reveal what exactly was said. Shortly afterwards, she admitted that being preto is ugly. In this dialogue, despite the fact that Fernanda classified herself as morena, she is probably identifying herself with the "raça preta" (black race) by admitting she was sworn at: "They yell 
at us with curse words. " Eduardo, 9 years old, branco (white), also said that he would not like to be of the raça preta because people say that preto, that there are people who make a lot of fun of preto person". I asked if he had already seen people making fun of pretos. He responded: "Yeah, they say things like this: Wow, you are so ugly. They say: You are so ugly you could only be preto." It was through this commentary that I noticed the force of the naturalization going on: if you are ugly you could only be preto, indicating an inevitable and necessary relation. Further on in the conversation, I asked Eduardo if he thought that a preto, while being called preto, would get angry. He then asked: "Yell at him that he's preto?" I asked: "Do you think this is a way of being yelled at?" He stated: "I think it is, saying it in one way." Neide, 10 years old, preta, while responding to the question "Is it better to branca than to be preta?" also revealed that brancos yell at preto person:

"Oh no! I prefer to be preta, but there are also other people that like, think that they are brancos and yell at us because we are pretas. But...but I like my color. Not me, it's not like I don't like branco (white) people. I also like branco (white) people, but it's just that....branco (white) people have been yelling at us, I don't care."

Neide said she had been yelled at by adults and children at school. When I asked her if the child that yelled at her at school was branca or preta he said: "She is preta, also, but she is lighter than me a little bit. She calls me annoying nega preta (black black girl)". ${ }^{9}$ Despite the fact Neide affirmed that "white people have been yelling at us," the classmate she referred to was not white, but was in fact "preta but lighter." Luzia, 8 years old, morena, affirmed that she would like to be white. One year after this conversation, I asked her if she remembered what we had talked about and she said: "I said I wanted to be branca and my sister wanted to be morena," which showed that this was a significant question for her. I then asked why she wanted to be white to which she answered: "I wanted [to be white] because the boys in class keep yelling at me...nega preta.” Afonso, 9 years old, preto, also wanted to be branco saying that: "I think it's very bad to be preto" because "they keep calling us charcoal.” I asked him to tell me who called him that and

8 Fernanda, as previously registered, did not believe that I considered her hair beautiful. She reacted to the question of whether she would like to be black in the following manner: "Oh God no! Not me."

9 The term "nega preta" means very "black". In some situations and/or regions it has a more pejorative meaning. 
he said: "the boys from the class...Geraldo and Aloísio call me preto, I mean charcoal." In their second interview, Aloísio, 10 years old, branco, admitted he would not choose to be preto, if it were a matter of choosing, because as he said "I don't like pretos very much." Later on he mentioned two pretos classmates (Diana and Luciano) and said that "when they arrived" they were called "preto, negão (big black guy), burnt charcoal, stupid pretos." It is important to highlight that he excluded himself from this act. Geraldo, 10 years old, moreno, commented in his second interview that it was not good to be "too preto because others keep calling us preto as charcoal". He said he was never called that because he is not preto. He mentioned two pretos classmates. In addition, he said he did not consider Diana to be pretty because she was too "preta." Further on in the conversation, he also added that he would not want to be preto "because [being] too preto looks like charcoal... and then people get even uglier." This once again signals the assumption that "preto is ugly" and that "preto look like charcoal", independent of the fact that he has two pretos brothers, according to what he had said. He also said that boys from the school shout "the boys that were pretos" from charcoal. In this revelation, Geraldo included himself among the boys that do this. When I asked him the reason for this kind of behavior, he answered: "it's because he looks like charcoal." Diana, 10 years old, preta, revealed that a classmate called her a monkey and nega preta (black black girl). Marília, 9 years old, preta, claimed that she heard a boy call a pretinho (little black boy) a monkey and considered this attitude "very ugly because they keep calling us monkey because they are also." This last phrase "because they are also" probably refers to those who are considered morenos, who by not considering themselves pretos make use of this kind of prejudiced verbal repertoire with ease. Marilia also stated that "white people" are not called monkey, but are called macarrão sem corante (colorless pasta). Fernanda, 8 years old, morena, after saying that pretos are called monkeys added: "but there are also white people who are called: hey, sour milk! How are you?” Ester, 12 years old, morena escura (dark morena), while explaining the attitude of a classmate that classified her as preto said: "he just keeps saying this because he is branco, hospital food ${ }^{10} . .$. he wanted to be branco, yeah yeah yeah, moreno also,

10 In the original account of the child, the expression 'macarrão da Santa Casa' refers to the pasta served at a philanthropic hospital known for its bad and colorless pasta. 
he became branco, he's jealous." Geraldo, 9 years old, moreno, identified a classmate as white in the following manner: "it's who is branco. Sebastião is branco, he looks like sour milk." Aloísio complemented Geraldo's statement by saying "whitey." Marta, 9 years old, morena, agreed with the statement made by Celina, 9 years old, morena when she said: "I prefer to be morena than branca". During the interview, Marta added: "That's right, because there are people who are Moreno [who] say to us like this: hey sour milk! They call us sour milk just because we are branco." It is worth mentioning that there are contradictions in these statements. Marta classified herself as morena yet in her speech she considered herself white, thus revealing she had already been called sour milk by a neighbor with "blond with frizzy hair". In addition, she later admitted to being called "nega preta": "because there are blonds who yelled at me, calling me nega preta (which made her conclude that being preto was not good because "when we see ourselves in the mirror, we feel ridiculous"). These contradictions suggest that the racial category morena was not a demeaning category as could be the case of the categories branco and negro/preto.

The previous interpretation produced by the group of the lower class children regarding the position of negros/pretos in racial relations can be summarized in the following sentences: "They yell at us with swear words", "there are people who make fun of negros", "they yell at us because we are pretos", and "white people keep yelling at us." Being made fun of and told off are components of the significant context of those relations. This hostile environment directed at negros/pretos was also revealed by Sara, 9 years old, morena clara (light morena). Stemming from my suggestion of words such as fighting, branco boy, preto boy and monkey, she created the following story:

"Once upon a time there was a white boy who had a monkey and that monkey was black. Then one day the boy decided to paint the monkey white, however the monkey started to fight...then the boy's father was preto and his mother was branca. Then the woman was having a baby. And the boy went to see her. So at the time, he saw the baby boy was preto. So he took paint and started to paint the baby's face, but that baby almost died. It was a little girl. Somebody came running and took the boy from there and threw him aside. Then the boy decided to paint himself preto. He kept painting; he painted the face, painted his eyes. Then everybody started running after him, yelling at him, kicking 
him, hitting him....then his mother hit him and decided to put the branco boy in the orphanage. The branco boy started to pick on all the preto boys there and to fight and everyone got hurt. Then at the end of the story, the two became happy and he said to the little girl that being preto was good and the little girl said that being branco was also good".

In this story, the white boy gets hit when he paints himself black. When he is white he tries to change the monkey's color and his sister's color, as well as ends up fighting with the preto boys at the orphanage. At the end of the story, the white boy concludes that "being preto is good" and the black girl comes to the understanding that "being branco is also good." The story reveals the child's view of the conflict between pretos and brancos and the aggressiveness directed at the former. It can be interpreted as an analogy to the daily reality lived by pretos girls and boys: the concrete possibility of being made fun of and yelled at. Furthermore, it reveals a conflict of racial identity that is resolved at the end of the story with the conclusion that "being preto is good" and "being branco is also good."

Some children did not verbally recognize the "suffering" felt by those considered to be negros/pretos. For example, a 10 year old branca girl admitted that a person of the raça negra (according to her classification) likes to be of the raça negra "because they don't feel anything." Sebastião, 9 years old, moreno, but considered whitey by two classmates, responded "no" when asked if calling a person preto could be considered as either telling someone off or being an offense. He said: "Depends on the color...because if it is a black person, then you can. Now it you are white, then it's just a nickname to me." This boy also claimed that he never heard a preto/negro person being yelled at or being made fun of.

Hence, the prejudiced language used by the group of the lower class children includes demeaning racial categories derived from the classifying categories such as nega preta (black black girl), neguim (little black guy), negão (big black man or guy), negona (big black girl), neguinha (little black girl), preto, negro, branquelo, in addition to other offensive categories such as charcoal, black as charcoal, monkey, devil, burnt charcoal, black donkey ${ }^{11}$, sour milk, colorless food, hospital food. As one can observe, the classifying category preta or negra can become transformed into a term of abuse. This

11 "Black donkey" refers to someone who is not considered intelligent. 
partially explains the rejection of this classification among the children. A 6 year old boy, for example, freely used the preta category, probably trying to aggressively provoke his classmate, whom he considered to be in a "privileged" position. This was because attention was being drawn to the classmate who was standing next to the teacher and was trying to have a closer look at the pictures in the book while the teacher was reading. When this classmate was called preta in the middle of the reading, the child left the side of the teacher, walked to the board, turned around and stood again beside the teacher without saying anything. Catarina, 11 years old, answered the teacher's question in the following manner ("So you never thought: Wow! Being black is ugly”): “Not me, others call me black but I don't mind.” This reveals how the category black is also a category of being yelled at, a form of aggression. This would be the hidden meaning behind her statement "but I don't mind".

The category nego preto (black black boy) was used or cited various times by the children. One day during recess, two girls were flipping through the magazine Race (Raça, issue 1). While the girls were looking at the magazine, a preto boy came across a picture of a Jamaican on page 108 and shouted: "Wow, what a nego preto! Nobody likes nego preto!" This opinion was confirmed by one of the children who responded: "Me neither." Shortly afterwards, I asked a group if they thought it was better to be Moreno than preto and the boy mentioned above answered the following: "I think it is better to be moreno. Being preto makes us look like monkeys. I already look like I'm a monkey." The spontaneity with which this child commented on his own negatively privileged position indicated a naturalization process of feelings and social ideas regarding boy referred to as nego preto. In addition, it signals a process of assimilation of the image produced by the stereotype.

In another conversation during recess, I asked a group of children to tell me about their color. When one of them answered morena, somebody contested saying "that's a lie, you pretinha (little black girl), which provoked laughter from the other children. Another classmate repeated: "She's preta. We call her 'little black bean' (feijãozinho preto)." On another occasion, also during recess, this same group of 7 year old children, sat next to me. I asked them the name of one of the children and as soon as Vera told me her name, another child said: "We call her little black bean." I asked why they did that 
and laughingly the classmate said: "Because she is a pretinha (little black girl)." I then addressed Vera and asked her: "Do you like this nickname?" However, before Vera could answer, the classmate said: “No, she doesn't like it." I then asked Vera: "What do you do when the girls call you that? What do you answer back?" Vera responded: "I hit them." Her classmate confirmed this by saying: "She runs after us, she kicks us." Even though the children are aware of Vera's dislike of this treatment, the children continue to call her in this manner.

The hostility towards the pretos/negros, especially those considered "preto as charcoal", explicitly used as a category to yell at others, was spontaneously expressed by a group of 8-9 year old children during recess when they came across the drawing on both the cover and page of the children's book "Little Black Boy from Pastoreio ${ }^{12}$." It was also at this moment that one could observe the association of negro/preto with dirtiness. According to the interpretation of these children, "the branco (white) man was yelling at the preto boy because he did not like preto. It's because he is negão (a big black guy), burnt charcoal, dirty. That's why he doesn't like him, he doesn't take a shower." At this moment, another child attacked the white man who was also drawn on the cover of the book saying: "And he's sour milk. This one here is sour milk." Another child added: "He doesn't accept preto." Even after these comments the conversation did not change: "He doesn't take a shower;" "Wait a minute he doesn't clean his butt;" "This neguim (little black guy) here, this guy". In relation to the other picture, the statements were as follows: "These three are laughing at him because he is black, because he pees in his pants"; "that's it, because he pees in his bed." At this moment I asked: "Why do you think he pees in his bed?" The children answered: "Because he is preto."

Upon entering a class of advanced 10 to 14 year old children, I heard a boy call Júlia negão (big black guy) to which she responded "go screw yourself." Three months after this conflict, in a conversation with another student from this class, she told me that Júlia's nickname was negão and Julião "because she is preta, morena escura (dark morena), but really dark." This comment omitted the masculine connotation in this nicknames and offenses. In another moment during recess break, I heard Júlia aggressively

12 This is a folk story in Brazil. 
being called neguinha da macumba ("little black macumba ${ }^{13}$ girl) by a boy. In addition, she was pushed from the sink from where she was washing her hands.

On a school trip to the zoo, which was organized by the teachers, I accompanied a group of 8-9 year old children. It was interesting to see that all of the children were very excited to arrive at the monkey and chimpanzee section, which happened to be the section that attracted the children. While the children were in front of the chimpanzees, Sebastião, 9 years old, moreno, but considered branco among his classmates, laughed at Diana, 10 years old, preta, saying: "These three could be your brothers." He left Diana's side as soon as another classmate answered back: "They could be yours too." The teacher asked what was happening and Renata, branca, said: "He said that those three chimpanzees could be Diana's brothers." The teacher reacted in the same manner as the child saying "They could be his also, right?" The teacher's comment provoked a timid laugh from Diana.

The preta/negra child is therefore the target of demeaning commentaries, even within a familial context. This makes us believe that the intimate acquaintance among people of various colors is not enough to prevent the use of racial stereotypes and offenses. In moments of conflict or tension, racial aggression can manifest itself against pretos/negros. What we see is that racial contact, in itself, does not contribute to the process of overcoming prejudice.

Sour milk, whitey, hospital food, colorless food all refer to people considered white. Even though there is the possibility of racial aggression against brancos, when there is a choice between being branco (white) or being preto/ negro, children choose or consider being branco (white) the better option. This shows us that the categories negro and preto occupy a more uncomfortable and vulnerable position, once this category can be easily considered as a constant target of hostility and inferiority rituals. A 9 year old girl, morena clara (light morena), but considered by many of her classmates to be branca, expressed the more comfortable position of broncos when she said: "if we are branco, nobody can give us a nickname because we are brancos and God made us."

13 Macumba is a popular form of referring to the rituals of Umbanda and Candomblé, which are Afro-Brazilian religions in Brazil. Sometimes the term macumba has a pejorative meaning. 
Fights and physical aggression are all forms of reacting to offenses and racial jokes ${ }^{14}$. Geraldo, moreno, claimed that he does not like to play with Luciano because "he keeps hitting others." I tried many times to talk to Luciano but he never wanted to talk, maybe because he realized what the conversation was about and therefore, was attempting to avoid it. Vera also reacted to the offense of being called feijãozinho preto (little black bean) by hitting whoever called her that. Vera admitted that she did not like anyone in the class, "except the teacher." Carolina, 10 years old, morena escura (dark morena), denied that her nickname was nega (black girl), as a classmate had suggested in a conversation, by saying: "don't listen to him, but when I get him he is going to regret the day he was born", threatening to hit her classmate.

Many children rejected the classification preto/negro, as another way of reacting. In many times, the reaction was accompanied by an exchange of offenses. This was the case of Ester, morena escura (dark morena), who answered a classmate back: "I'm not preta, ok João! And you are sour milk". Another case was that of Ronaldo who also disagreed with a classmate saying: "It's a lie, I am not a preto escuro (dark black), alright you dog?...I'm not, I'm not preto!" Gerson, 10 years old, marron (brown), despite affirming that "color has nothing to do with it," said he would not choose being preto and stated the following: "I don't like that color very much." Later on, he remembered Michael Jackson and interpreted Jackson's actions as "wanting to become white." He stated: "Well, because he thought they, the people, would not like him."

A more radical consequence of the rejection of the category preto/negro is the desire to change color, which was expressed by various children. Paula, 9 years old, negra/morena, said she did not like being preta because the "color is ugly". Paula went on to further claim she would like to be white. Vanderlei, 8 years old, Moreno, also said he would like to be white. Luzia, 8 years old, morena, also admitted that she would like to be white claiming that she is

\footnotetext{
14 On a macro level of discussion, Blalock (1982: 105-106)provides four alternatives that are open to a racial or ethnic minority (groups in a subordinated position and therefore in weaker positions of power) and individual members: 1) the attempt of the minority to disappear as a distinct group, "assuming its members can 'pass' on as members of the majority or that their minority status can lose its conspicuousness or relevance to members of the dominant group"; 2) the attempt of the minorities to isolate themselves from the majority of those from the majority group or the attempt of individual members who "may attempt to 'escape' from important encounters with the majority;" 3) the attempt of the minority to find partners to form a coalition, "pooling resources in order to gain power in relation to the majority;" and 4) the attempt of the minority "to engage in a power struggle with the dominant group, without benefit of coalition partners."
} 
often offended and called nega preta. When asked if she also thought she was a nega preta she said "yes because that's what they call me". This statement reveals her acceptance of this identity as real.

The expression "color has nothing to do with it" is equivalent to the expression "color doesn't matter." Ester, morena escura (dark morena), three months after refusing the classification as preta, said that she did not get upset if someone called her preta because "color doesn't matter." According to the claims made by the children, we can infer that the expressions "color has nothing to do with it" and "color doesn't matter" are in fact expressing more a desire than a reality. It is as if the children wanted to say that color should not matter and should not have anything to do [with things], given that what they see and experience in their interactions are the contrary of these statements.

Among the children of the middle class, the demeaning racial categories and offenses are also recognized and used. This is a group composed of a minority of pretos/negros, according to the children's classification. The many accounts presented and discussed here refer to racial relations in which the interviewed children do not directly experience, but should be considered as a verbalization of their perception of the experience of being preto/negro. Mércia, 9 years old, morena, ("I was born white, white, I looked transparent; but it's like I would always go to the beach") claimed that she saw "a man on a motorcycle yell at a dark person, saying...racist right? Then the other man got quiet because he must have thought that if he tried to fight it would not lead to anything and then I could see the other man was really sad."Eliane, 9 years old, morena, also heard someone on the streets saying to a man "hey you ugly neguinho (little black guy), just because he was black." I asked Nestor, 9 years old, meio moreno e meio branco (half moreno and half white), after he told a joke in which a black person desired to be white, if in real life blacks would also like to be white. Nestor gave his opinion in this manner: “Some don't like their color because it's that...but, I don't make fun of them, but there are some people that say: hey big monkey, hey Creole! Then...then you are going to want to be white, right?" He revealed that he laughed when a "moço branco" (white man) yelled at a "pretão" (very black man) in the middle of the streets because "it was funny."

The fact that there are categories for offenses derived from the branco category and negro/preto category does not mean that they carry the same 
negative weight and offense. Nor does it mean that they influence the selfesteem of children in the same manner. Sandra, 10 years old, morena, spontaneously started a conversation with me at the school while she was waiting for her father to pick her up. She talked about a preta classmate that "many people discriminated". She said that in the beginning of the school year this girl was offended and yelled at by some girls and boys who called her nega do cabelo duro (black girl with hard hair) and would sing to her "black girl with hard hair, what comb can comb your hair?" After we talked about the meaning of the words discrimination, racism and about racial classification, I asked her if negros and pretos would get upset if called pretas. Sandra responded: "I think they do. Some people don't because they are already used to it. Because they don't like this, because people keep saying this and they can get very upset." I then asked her if a white person would get upset upon being called white. Sandra then answered by saying: "no."

In various dialogues, the possibility of a preto/negro being made fun of "just because he/she is preto/negro" was emphasized. Making fun of others is a recurrent social practice and characteristic of socialization among peers. This practice is considered a child's thing by adults and is often not taken seriously; however, it becomes an efficient social mechanism of acquisition, consolidation and objectification of a prejudiced and psychologically violent social order. When a child is asked why he/she yells at, offends or makes fun of a colleague, the child claims that such actions are only a game. ${ }^{15}$

Aparecida, 11 years old, negra, stated that she did not like Glauber, a classmate because "he is very annoying...he keeps calling me whale, negona (big black girl)". Aparecida reacts to these remarks in this manner: "I pretend I don't hear them." Further in the conversation she also said she did not like Fabrício for the same reason. According to Aparecida, the two classmates are brancos. Even though she has been racially offended and made fun of, when I asked her to explain the meanings of the words prejudice and racism, she said she did not know. Our conversation continued about a variety of topics. When I asked her if there were other negro classmates she

15 Thorne (1995: 79) analyzes the meaning of the definition of a situation such as "play" stating that it is a very fragile definition: "participants have to continually signal the boundary that distinguishes play from not play, and play and humor easily slide in and out of other, more 'serious' meanings. This ambiguity creates tension, since one is never sure in what direction it will swing; [...] the ambiguity lessens potential risks and leaves room for denial”. 
said: "there is one more." Aparecida claimed that the reason this other classmate was not made fun of is: "because he is...he is a little bit whiter." Her answer reveals that she interprets her position to be a disadvantageous one in social relations due to the darker color of her skin. Her evaluation here is interesting, particularly since she did not have the necessary conceptual resources to defend herself, such as knowing the definition of racism.

Knowing that these games and fights are phenomena that are particularly important for the socialization of children, it should be noted that the possibility for being made fun of and for being the targets of racial offenses/ slurs make the time-space of socialization among peers a promising and basic field for the development and formation of racial prejudices. There are various reasons why a fight might take place among children. A fight on a given day does not imply in permanently breaking friendship ties, as one girl stated: "we get mad one day and tomorrow we are already ok." What is significant about these moments is the mobilization of offenses and racial aggressions, even if the fight is about something else and not a racial question. Therefore, through this common and frequent practice among children, who fight among themselves and consider some classmates annoying, racial prejudice begins to entrench itself, thus becoming a reality in itself.

The offensive practices, as well as the racial jokes make the moments of integration that could be relatively harmonious into fragile and unstable ones. Hence, such moments always become a threat to those who are vulnerable, particularly those given the label of being negro/preto. However, this does not mean that after unleashing racial aggression it is not possible to restore the previous situation. American studies with younger children have identified more than a paradox between attitude and behavior (prejudiced attitude and non-prejudiced behavior). It seems that in the world of children, as observed here, there is a permanent oscillation between an integrating situation and a prejudiced one. In the moments when there is a rupture of the relationships, social and aggressive resources are available and are used, creating the fulfillment of a demarcation ritual of racial status.

In Thorne's (1995) analysis of the meaning of gender in the relations among boys and girls, she uses the concept of borderwork. As the author informs us, this term comes from Barth's (1969) analysis "of the social relations that are maintained across ethnic boundaries without diminishing the participants' 
sense of dichotomized ethnic status" (Thorne 1995: 64). For Thorne (1995), the active meaning of difference can be reduced through contact, but the interaction of groups can also occur and strengthen these frontiers.

When gender boundaries are evoked through various types of borderwork (the author describes and analyzes "contests," "chasing", "cooties and pollution rituals," and "invasions"), Thorne (1995: 66) states that:

“...they are accompanied by stylized forms of action, a sense of performance, mixed and ambiguous meanings (the situations often teeter between play and aggression, and heterosexual meanings lurk within other definitions), and by an array of intense emotions - excitement, playful elation, anger, desire, shame, and fear".

In the same manner that gender boundaries are evoked through various types of borderwork, racial frontiers are also evoked through daily practices of offenses and games.

Another relevant aspect from the children's statements in the two groups observed was the presence of a relativized discourse on racial prejudice. In this discourse, religious arguments ("everyone is still a child of God"), as well as secular arguments ("we are all human") were given by the children. In addition, the dichotomy internal and external was present ("the blood is the same", "inside everyone is the same"). Despite the fact that some studies interpret this discourse of equality as a form of hiding racial prejudice and not contributing to forms of overcoming prejudice, this study finds this type of discourse important among the children. In this study, such discourse is seen as having the objective of emphasizing the creation of a critical sense in the socialization process that would then be capable of transforming racial prejudice into a condemned and unacceptable social practice. In this sense, the relativized discourse and racial prejudice are components of the process of socialization among children, and both are in a process of being crystallized and stabilized during childhood. The ambiguous character of the Brazilian racial relations ideology is clearly illustrated in the discussions by Nogueira (1955: 514) when the author affirmed that this ideology was made up of “...on the one hand, by prejudice, and on the other hand by the ideals of racial equality and of miscegenation". 


\section{Final Considerations}

As this study shows, the socialization among peers constitutes both a privileged space and time, where beliefs and racial ideas already learned are experimented and tested out by children. In addition, it is among these interactions that children begin to learn what it means to be of one racial category in comparison to another, creating and recreating the social significance of race. Therefore, the study showed how a type of game of classification and racial self-classification in which a process of negotiation, manipulation, and dispute over not being identified as from the preto/negro category was established. This game becomes more intense given the recognition of a system of multiple racial categories in Brazil. The drama behind this game is the negativity associated with the category preto/negro, which exposes the children classified in this category to a ritual of inferiority, particularly expressed through mockery and name calling.

The racial reality established by the daily relations among the children expresses the ambiguity of the racial discourse acquired through a cultural definition of the concept of race in Brazil. Hence, at the same time the children carry out and express prejudiced attitudes, a discourse of equality circulates among them.

The attempts towards creating a society without racial prejudices demand policies that are capable of establishing a change in the elaboration of the discourses on the preto/negro category, as well as, of problematizing the very notion of race, which is at the base of racism.

Nogueira (1955: 518) considered that the type of ideology on Brazilian racial relations would facilitate the operation of "rational processes of modifying attitudes and conceptions that pertain to the sphere of racial relations", since contrary to other societies, prejudice still had not created a profound antagonism among whites and non-whites in Brazil. This ambiguity is also being constructed by the children and also points to potential forms of overcoming prejudice. This is because it makes room for anti-discriminatory arguments that have not been racialized. Fry (2005: 164) also recognizes the presence of a tension in Brazil "between the ideals of a mixed race and of non-racism $[. .$.$] and the historic racial hierarchies dating back to the 19^{\text {th }}$ century" and concludes that

"the ideals of non-racism and the liberation from any 'racial' determination, which in Brazil have become the official ideology for many years and 
have established the world vision of many Brazilians today, are values that are becoming increasingly rare in the contemporary world so much so that these ideals are worth being taken seriously”. (Fry 2005: 165).

Another aspect to consider when formulating non-racist policies is the process of establishing racial categories. Hirschfeld's (1996) research with North American and European children disagrees with the studies on the acquisition of racial and ethnic conscience that assume a visual experience (appearance) as one of fundamental importance in the construction of racial categories by children. The author claims that "rather than being overly dependent on appearances, young children's racial concepts involve encoding and retrieval processes that are in many ways, independent of perceptual factors" (Hirschfeld 1996: 136). For Hirschfeld (1996), the integration between perceptual and conceptual knowledge can be less than what is usually imagined. He suggests that this integration develops during preschool and early school years, which is contrary to other researchers who affirm that during this period, there is considerable conceptual development with regard to racial thought. Therefore, "what happens during the late preschool years may be less a restructuring of the conceptual system than an accumulation of factual knowledge about the culturally relevant perceptual correlates of the concept in question" (Hirschfeld 1996: 137) or as "an alignment of initially relatively distinct verbal and visual categories" (Hirschfeld 1996: 154). For the author, younger children initially worry about the elaboration of a conceptual understanding of race and only later worry about the ways in which individuals can be respectively distinguished. Their attention is more focused on verbal or discursive clues than visual ones. The initial understanding of race for the child is not derived from observed differences, but instead on discursive information. The racial categories of younger children contain less perceptual knowledge and more conceptual knowledge. According to Hirschfeld (1996), younger children have a theory about society or "expectations about the entities of society and their nature" (Hirschfeld 1996: 119). For the author, race is one of the central components of children's naive theory about society. The acquisition of racial categories is embedded in the acquisition of a folk sociology. One of the characteristics of folk theory on race is the belief that "racial differences [...] are thought to encompass non obvious or inner qualities (including moral and mental ones) as well as outward physical ones" (Hirschfeld 1996: 42). This belief, as 
the author claims, is "one of the most malign aspects of folk theory, because it is so closely bound to (and enabling of) racial prejudice" (Hirschfeld 1996: 53). Racial prejudice is learned through a discursive elaboration of the concept of race given that the racial categories promote conceptual and evaluative inferences, such as "members of some groups are intellectually dull, aggressive, or dirty” (Hirschfeld 1996: 189).

When one brings this discussion to the field of policies that combat racial prejudice in Brazil, some questions are sketched out: how is it possible to create non-prejudiced racial relations given that prejudice is a component of a folk theory of race, and is discursively learned, conceptually elaborated, and tested in established social interactions starting with 5 year old children? The use of racial discourse by children, in their collective activities, and the attempt of the juxtaposition of verbal and visual categories enable children to learn and understand the meaning of social life, particularly of racial categories. It is in this constructed sense that the category preto-negro finds itself at the lowest level of consideration, being therefore interpreted as inferior.

Will racial policies that seek to strengthen one's identity and racial pride, as the kind being implemented in Brazil, be able to identify the genesis of the processes of prejudice? Wouldn't this lead to the risk of strengthening the belief in differentiated races according to a discourse that questions, for example, the "myth of racial democracy" as one which conceals the reality of racism?

There is yet another aspect to be considered. Katz (1982) concluded that according to her research on stereotyping, perceptive mechanisms could be attributed to the development and maintenance of prejudice. Therefore, for the author, the more one emphasizes the differences among racial groups and ignores the individual differences among members of a minority group, the more one reinforces the perceptive base for the maintenance of prejudice. Considering this conclusion to be plausible, one can assume that the emphasis on the need for an ethnic-racial affirmation can have an effect of strengthening prejudice instead of overcoming it. Would the struggle for equality, based on a politics of racial identity officially established, be a contradiction to the objective of an anti-racist struggle? Would the attack upon the multiple, racial and ambiguous system of classification in Brazil and its substitution with an almost forced bipolar system black-white lead 
to the strengthening of the belief in natural and real identities and racial categories? Could there be another alternative to facing racism? This study does not have any definitive answers to all of these questions. What this study hopes to have demonstrated is the complexity of the problem of the genesis of racial prejudice and the daily drama lived by children identified as preto/negro. In the Brazilian case, I believe the attempt for anti-racist policies, which seek to deepen the debate regarding the ambiguity of the prejudice/egalitarian discourse, should try to deconstruct the belief/idea of differentiated human races and consequently, should try to deconstruct the concept of race, a basis of racism.

Received August 4, 2014, approved January 7, 2015

Revised by Peter Fry

Translator: I would like to thank Ana Carolina Ogando for her help in translating this article.

\section{References}

BARTH, Fredrik. 1969. "Introduction”. In: F. Barth (ed.), Ethnic groups and boundaries. Boston: Little Brown. pp. 9-38.

BLALOCK, Hubert M. 1982. Race and ethnic relations. New Jersey: PrenticeHall.

CICOUREL, Aaron V. 1974. Cognitive sociology - language and meaning in social interaction. New York: The Free Press.

FAZZI, Rita de Cássia. 2006. O drama racial de crianças brasileiras- socialização entre pares e preconceito. Belo Horizonte: Autêntica.

FRY, Peter. 2005. A persistência da raça - ensaios antropológicos sobre o Brasil e a África austral. Rio de Janeiro: Civilização Brasileira.

GLASER, Barney G. \& STRAUSS, Anselm. L. 1970. The discovery of grounded theory - strategies for qualitative research. Chicago: Aldine Publishing Company.

HIRSCHFELD, Lawrence A. 1996. Race in the making - cognition, culture, and the child's construction of human kinds. Massachusetts: The MIT Press.

KATZ, Daniel \& BRALY, Kenneth W. 1966. "Verbal stereotypes and racial prejudice”. In: H. Proshansky e B. Seidenberg (eds.), Basic studies in social psychology. New York: Holt, Rinehart and Winston. pp. 266-272. 
KATZ, Phyllis A. 1982. "Development of children's racial awareness and intergroup attitudes". In: L. G. Katz, (ed.), Current topics in early childhood education, vol.4. New Jersey: Ablex Publishing Corporation. pp. 17-54.

LERNER, R. M. \& LERNER, J. V. 1986. "Contextualism and the study of child effects in development”. In: R. L. Bosnow \& M. Georgoudi (eds.), Contextualism and understanding in behavioral science. New York: Praeger. pp. 89-104.

MEHAN, Hugh \& WOOD, Houston. 1975. The reality of ethnomethodology. New York: A Wiley-Interscience Publication.

NOGUEIRA, Oracy. 1985. Tanto preto quanto branco: estudos de relações raciais. São Paulo: T. A. Queiroz Editor.

. 1955. "Relações raciais no município de Itapetininga". In: R. Bastide

\& F. Fernandes (orgs.), Relações raciais entre negros e brancos em São Paulo. São Paulo: Anhembi. pp. 362-554.

THORNE, Barrie. 1995. Gender play: girls and boys in school. $4^{\mathrm{a}}$ edição. New Jersey: Rutgers University Press.

VALLE SILVA, Nelson do. 1994."Uma nota sobre 'raça social' no Brasil". Estudos Afro-Asiáticos, 26: 67-80.

---. 1985. "Updating the cost of not being white in Brazil". In: P. M. Fontaine (ed.), Race, class and power in Brazil. Los Angeles: Center for Afro-American Studies. pp. 42-55.

Rita de Cássia Fazzi

Pontifical Catholic University of Minas Gerais rfazzi@pucminas.br / rita.fazzi@gmail.com 